\title{
Utilization of Fermented Cocoa Pod Husk (CPH) as Feed Ingredient for Sheep
}

\author{
Susana IW Rakhmani ${ }^{1 *}$ and Wisri Puastuti ${ }^{1}$ \\ ${ }^{1}$ Indonesian Research Institute for Animal Production, Jl. Veteran III Ciawi Bogor, West Java, Indonesia \\ "Corresponding author.Email:susanawijaya@yahoo.com.au,susanawijaya35@gmail.com
}

\begin{abstract}
The experiment of sheep feeding with concentrate contained fermented cocoa pod husk (FCPH) has been conducted at the IRIAP research station. The experiment aimed to study and evaluate FCPH product for sheep. Fermentation of cocoa pod husk using Aspergillus oryzae was carried out for three days. The FCPH product was dried and ground. A feeding trial experiment was performed on weaned rams with 6 replications ( 6 heads) / treatment for 2 weeks of adaptation and 12 weeks of observation. The basal diet was chopped king grass, and the treatments applied as follows: Control (C: king grass+commercial concentrate), C20 (20\% commercial concentrate was replaced with 20\% FCPH), and C40 (40\% commercial concentrate was replaced with $40 \% \mathrm{FCPH})$. The crude protein content of FCPH was higher than CPH (15.94 vs. $6.71 \%$ ). Replacement of commercial concentrate with 20 and $40 \%$ of FCPH increased protein digestibility from 45.32 (C) to 55.35 (C20) and 60.25 (C40), NDF digestibility was 50.14, 57.16, and 67.19\%, for C, C20, and C40, respectively. The average dry matter consumption ranged from 600-900 g/head/day). The feed conversion ratio (FCR) at the adaptation week was very high (21-23.6). Moreover, the FCR was better during the observation period with a value of 14.02, 9.56, and 8.4 for C, C20, and C40, respectively. Bodyweight gain for C0, C20, and C40 was 65.80, 80.64 , and $85 \mathrm{~g} / \mathrm{head} / \mathrm{day}$. Rumen chemical characteristics were as follows: rumen ammonia in C40 was the lowest compared to $\mathrm{C}$ and $\mathrm{C} 20$. Meanwhile, the rumen $\mathrm{pH}$ ranged between 5.88 and 6.05. Acetic acid dominated the rumen environment, the level was $28.68 \%$ (C20), 31.37\% (C), and $47.38 \%$ (C40). The content of VFA also indicated normal rumen digestive conditions. The biological processing of $\mathrm{CPH}$ increased the digestibility of protein and neutral detergent fibre. Cocoa pod husk fermented using Aspergillus oryzae can be used to replace commercial concentrates as much as 20 and $40 \%$ without causing a negative effect.
\end{abstract}

Keywords: Cocoa pod husk, Aspergillus oryzae, sheep, feeding

\section{INTRODUCTION}

Feed accounts for $65-75 \%$ of the total cost, and feed quality in the livestock business is essential, and its availability is not always met. For Indonesia, most of the feed ingredients (corn, soybeans) are still dependent on imports. As an agricultural country, Indonesia develops variety of agricultural /plantation commodities such as palm oil and cocoa. Indonesia is one of the top 5 cocoaproducing countries in the world and stay in the $3^{\text {rd }}$ rank [1]. The overall annual production is 849,875 tons, with the majority coming from Sulawesi, and South Sulawesi alone produces $70 \%$ of Indonesia's total cocoa production [2]. The proportion of waste by-products was
$60 \%$ or 509,925 tons, equivalent to 152,977 tons of dry matter, which can accommodate around 115 thousand livestock units per year. Processing of cacao pod husk $(\mathrm{CPH})$ into silage (North Sumatra) and fermentation using Aspergillus niger (South and Southeast Sulawesi, and Bali) and other biological agents (microbial) has been carried out. However, complete information on the characteristics of the products has not been available.

Several researchers have used various fungi for the $\mathrm{CPH}$ fermentation process, namely; Aspergillus niger, Rhizopus oligosporus and Trichoderma resee [3], A. niger, Pestalotiopsis guepinii, Rhizopus oligosporus and Mucor circinelloides [4] [5], Phanerochaete chrysosporium [6], and Aspergillus sp [7]. $\mathrm{CPH}$ 
fermentation using A. niger can reduce crude fibre content by $5.5 \%$ [8], and coconut cake fermentation using A. niger can reduce crude fibre content by $4.91 \%$ [5]. Fermentation of $\mathrm{CPH}$ showed an increase in protein content of $9 \%$ to $12 \%$ after fermentation with A. niger [3] and $13.38 \%$ [8]. Fermentation of $\mathrm{CPH}$ using A. oryzae can produce fermented $\mathrm{CPH}$ products with protein content reached $15.00 \%$ [8]. In this article, the product of A. oryzae fermented cocoa pod husk (FCPH) was used to replace 20 to $40 \%$ of feed concentrate in sheep feeding and evaluate the benefits of FCPH as a component of sheep feed concentrate.

\section{MATERIALS AND METHODS}

\subsection{Materials}

The fungus A. oryzae, was from the Balitnak culture collection. Cocoa pod husk (CPH) was collected from a plantation in West Bandung. Other chemicals purchased from the respected supplier were either pro-analysis grade or technical grade.

\subsection{Methods}

\subsubsection{General methods}

A. oryzae powder form was made according to previous study [9]. The mold was inoculated into rice media and incubated for 3 days. The spores formed were dried at $40^{\circ} \mathrm{C}$ and then ground to obtain the inoculum in powder form.

Cocoa pod husk (CPH) was chopped, sun-dried, and then ground. The dried substrate was added water up to $60 \%$ water content and then steamed for 30 minutes, stand to lukewarm, then a mineral mixture (consisting of $1 \%$ ZA, $0.5 \%$ urea and other macro minerals) was added. Fermentation lasted for 3 days with a substrate thickness of 1-2 cm on plastic trays. Laboratory analysis includes analysis of chemical composition (Proximate analysis: Dry Matter, Crude Protein, Crude Fibre, Fat, Ash, NDF, ADF, lignin), in vitro and in sacco digestibility,

Experiments on livestock using 3 ration treatments as follows: C0 (Control: King grass + feed concentrate); C20 (King grass $+80 \%$ Feed Concentrate $+20 \%$ FCPH $)$ and C40 (King grass $+60 \%$ Feed Concentrate $+40 \%$ FCPH). In this study, weaning rams were used with 6 replications (6 heads) per treatment.

\subsubsection{In sacco and in vitro pepsin Digestibility}

The in sacco test was carried out to determine the level of FCPH degradability in the rumen as a source of protein for ruminant feed. Sheep with rumen fistula were given basic feed sufficient for basal living needs $(50 \%$ grass and $50 \%$ concentrate). Feeding the sheep was done 2 times a day in the morning and evening. Five grams of the sample was put into a nylon bag that was surface-tied and weighted. The bags were incubated in the rumen for $0,2,4,8,12,24,48,72$ and 96 hours. After going through the specified incubation period, the nylon bag was washed with running water until it was clean and dried in an oven $\left(50-60^{\circ} \mathrm{C}\right)$ so that a constant weight was obtained Protein and fiber were analyzed and digestibility was calculated.

Furthermore, protein digestibility by pepsin was also tested as a measurement of post-rumen digestibility. Post-rumen crude protein digestibility (in vitro) was tested by measuring the sensitivity of the feed to the pepsin enzyme under acidic conditions [10, 11]. Weighed as much as $2 \mathrm{~g}$ of the remaining sample of the in sacco digestibility residue for 24 hours and put into a fermentation tube. Then $20 \mathrm{ml}$ of $0.2 \%$ pepsin in $0.1 \mathrm{M}$ $\mathrm{HCl}$ was added to the tube and incubated at $39^{\circ} \mathrm{C}$ for 24 hours. After 24 hours of incubation, it was filtered using a sintered glass filter (G2). The remaining feed was analyzed for crude protein content

\subsubsection{Feeding trial}

All sheep were placed in individual cages of 20 stilts for easier observation. Placement of livestock in cage plots was carried out randomly according to the type of feed as treatment. Prior to the research, the sheep were given time to adapt to the cage environment and feed for 14 days with experimental rations. All sheep were dewormed using Kalbazen during the adaptation period. Prior to the study, all animals were weighed live to obtain initial weight data.

During the study, the amount of concentrate feed was $2 \%$ of live weight based on dry matter (NRC, 1975). The concentrate was given before the grass. The remaining concentrate and grass were weighed the next day to determine consumption. Drinking water was available continuously in the cage. Live body weight during the study was carried out every week, in the morning before feeding and drinking water. The experiment was carried out for 3 months

The experiment was carried out using a completely randomized design.

\section{RESULTS AND DISCUSSION}

\subsection{Fermentation}

The growth of $A$. oryzae on days 2 and 3 can be seen in Figure 1. The CPH substrate was filled with A. oryzae mycelia. At this stage, the mold has not yet started to form spores and was the highest protein content phase. Chemical composition analysis (Proximate analysis: dry matter, Crude protein and fibre, fat, ash, NDF, ADF, and lignin) of CPH and FCPH showed in Table 1. Crude protein content increased from $6.71 \%$ before 
fermentation to $15.94 \%$ after fermentation. The nitrogen content was equivalent to $2.55 \%$, while the addition of nitrogen from ZA (1\%) and Urea $(0.5 \%)$ contributes an additional $0.45 \%$ of nitrogen so that the net nitrogen content in FCPH was $2.1 \%$ or equivalent to $13.16 \%$ protein and an increase of $196.11 \%$. Another result was the fat content decreased by $22.03 \%$; from 2.36 to $1.84 \%$.

\subsection{In vitro and in sacco digestibility}

The highest dry matter loss in sacco occurred in FCPH, which was 200-360 g/kg. Meanwhile, CPH without fermentation was $100-300 \mathrm{~g} / \mathrm{kg}$ of material.

Table 1. Proximate analysis of $\mathrm{CPH}$ and $\mathrm{FCPH}$

\begin{tabular}{|l|r|r|}
\hline Component & CPH & FCPH \\
\hline Moisture (\%) & 9.88 & 5.4 \\
\hline Crude Protein (\%) & 6.71 & 15.94 \\
\hline Fat (\%) & 2.36 & 1.84 \\
\hline Gross Energy (kcal/kg) & 3814 & 3983 \\
\hline Crude fibre (\%) & 42.71 & 48.39 \\
\hline Ash (\%) & 10.19 & 11.25 \\
\hline Ca (\%) & 0.49 & 0.5 \\
\hline P (\%) & 0.1 & 0.11 \\
\hline NDF (\%) & 68.63 & 79.09 \\
\hline ADF (\%) & 64.58 & 71.36 \\
\hline Lignin (\%) & 30.7 & 35.36 \\
\hline
\end{tabular}

Meanwhile, it was reported that digestibility in sacco with an incubation period of 48 hours for rice straw, Acacia auriculiformis, sugarcane shoots, and Acacia mangium were 25, 30,30 and 32\%, respectively [12]. Dry matter digestibility in sacco $\mathrm{CPH}$, FCPH in 48 hours incubation were 25.4 and $35.11 \%$ (Figure 2), equivalent to the above ingredients except for FCPH (35.11\%), which was higher than Acacia sp and sugarcane tops.

The highest loss of protein content or protein digestibility in sacco occurred in KBCFAn while KBCFAo was the lowest compared to $\mathrm{KBC}$ and KBCFAn. The low digestibility of protein in sacco allowed digestion in the post-rumen digestive system. Such conditions are desirable so that with the help of enzymes in the intestine. protein can be digested into amino acids and can be absorbed by livestock (Figure 3 ).

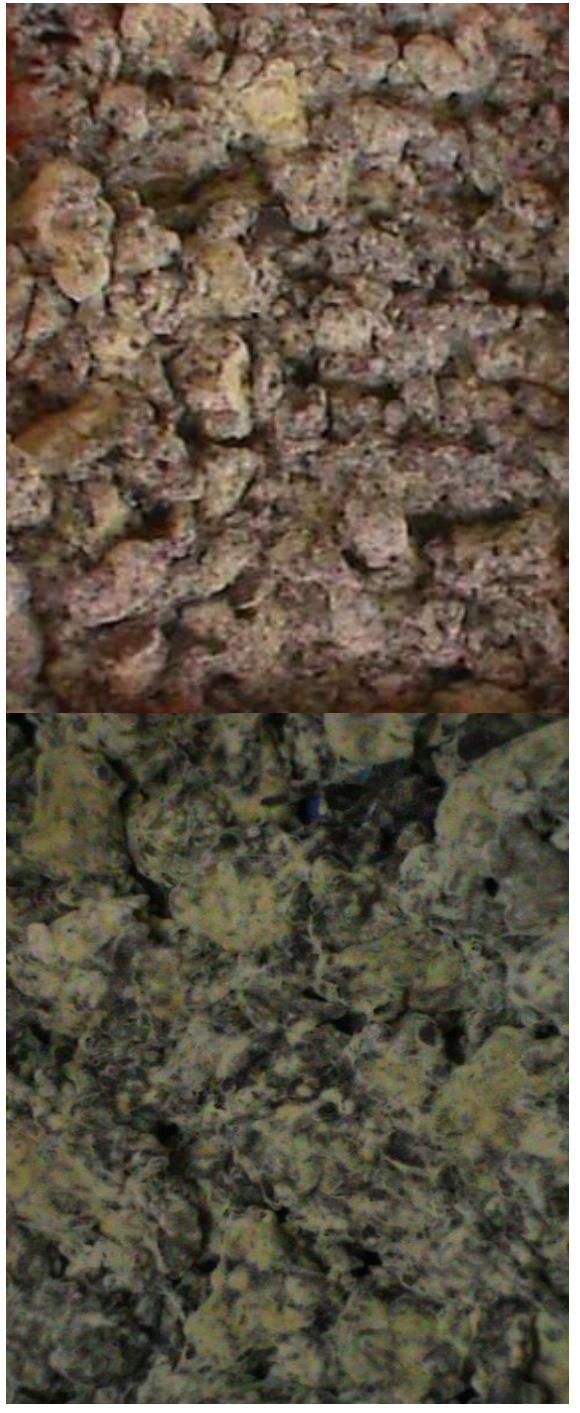

Figure 1. FCPH fermentation day 2 (above) and day 3 (below)

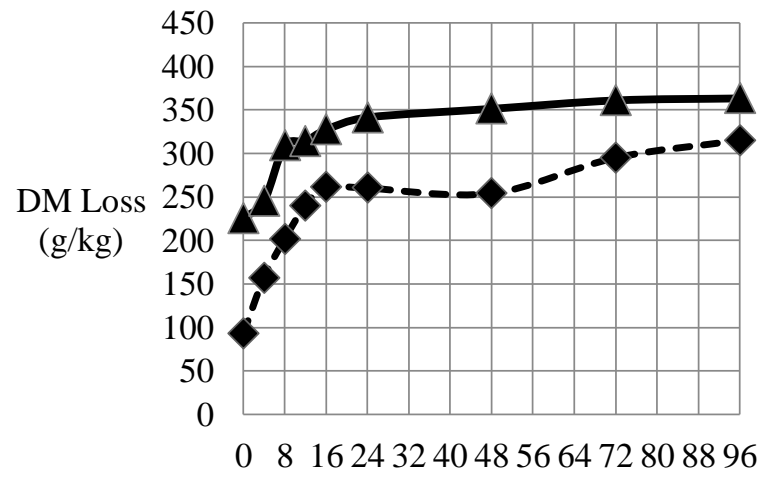

Incubation (hours)

Figure 2. Dry matter loss in sacco of FCPH (upper line) and $\mathrm{CPH}$ (lower line) 


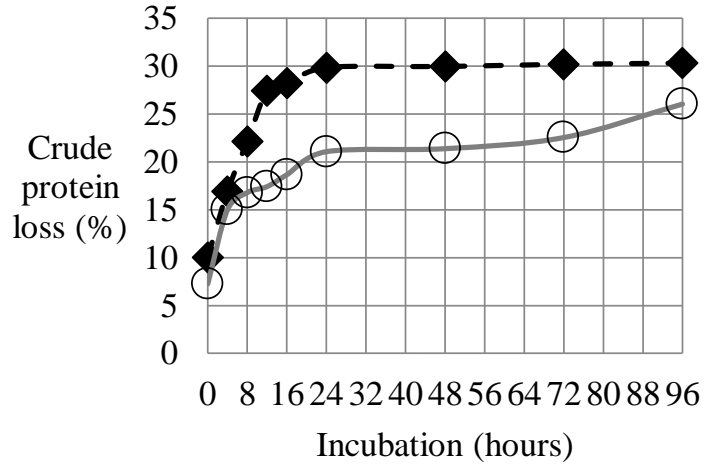

Figure 3. Protein loss in sacco of FCPH (lower line) and $\mathrm{CPH}$ (upper line)

The digestibility of protein and in vitro NDF (rumenpepsin) of feed ingredients and rations can be seen in table 5. Replacement of concentrate with FCPH 20 and $40 \%$ increased protein digestibility from 55.32 to $60.25 \%$ and NDF from 57.16 to $67.19 \%$. It was confirmed that FCPH contains fibre hydrolase enzymes, including mannanase $(1700 \mathrm{U} / \mathrm{g})$, and contribute to increase DM loss in FCPH.

\subsection{Feeding trial}

Feeding trial shown no difficulty in sheep accepting feed concentrate containing $20 \%$ and $40 \% \mathrm{FCPH}$.

Nutrient content of feed at the beginning and end of the study especially protein content, varied between 15 and $18 \%$. Protein content at the beginning of experiment was $17.91(\mathrm{C} 0) ; 16.27(\mathrm{C} 20)$ and $16.70 \%(\mathrm{C} 40)$ and $15.58(\mathrm{C} 0), 15.59(\mathrm{C} 20)$ and $14.12 \%(\mathrm{C} 40)$ at the end of the experiment. Replacement of concentrate with 20 and $40 \%$ of fermented cocoa pod husk increased protein's digestibility from 55.32 to $60.25 \%$ and NDF of 57.16 to $67.19 \%$.

Table 2. In vitro digestibility of protein and NDF of feed materials

\begin{tabular}{|l|lll|rll|}
\hline \multirow{2}{*}{ Materials } & \multicolumn{6}{|c|}{ Digestibility } \\
\cline { 2 - 7 } & \multicolumn{3}{|c|}{ Protein (\%) } & \multicolumn{3}{c|}{ NDF (\%) } \\
\hline CPH & 48.96 & \pm & 1.40 & 49.50 & \pm & 0.76 \\
\hline FCPH & 64.35 & \pm & 0.55 & 61.83 & \pm & 0.76 \\
\hline King Grass & 70.02 & \pm & 0.60 & 66.99 & \pm & 1.74 \\
\hline K0 & 55.32 & \pm & 0.72 & 57.16 & \pm & 0.83 \\
\hline C20 & 59.67 & \pm & 1.02 & 66.09 & \pm & 3.60 \\
\hline C40 & 60.25 & \pm & 1.09 & 67.19 & \pm & 1.49 \\
\hline
\end{tabular}

Daily live weight gain followed the pattern of the $3^{\text {rd }}$ order polynomial equation. In comparison, the analysis of variance on live body weight was not significantly different compared with control. Daily live weight gain ranged between $65-85 \mathrm{~g} / \mathrm{head} / \mathrm{day}$. Dry matter intake ranged between $600-900 \mathrm{~g} / \mathrm{head} / \mathrm{day})$. Results of analysis of variance on dry matter intake within treatments was significantly different.

Feed conversion ratio (FCR) two-weekly intervals during the adaptation period was high (between 21 and 23.6) and for subsequent trial weeks, ranged between 8.48 and 14.02. The FCR between 9.53 to 12.3 was reported for yearling sheep when wheat bran was partially replaced by air-dried Moringa stenopetala [13] for 70 days trial.

Analysis of variance for FCR was significantly different between treatments.

Intake, excretion, and absorption of protein in sheep for $\mathrm{C} 0, \mathrm{C} 20$ and $\mathrm{C} 40$ ranged from $90-100 \mathrm{~g} / \mathrm{h} / \mathrm{day}$, with up to $60 \%$ being absorbed and the rest eliminated in urine and feces. Protein intake was not significantly different between treatments. Fiber intake (measured as neutral detergent fiber, NDF) between 400-600 g / h / day and $50 \%$ metabolized in the body. The rest was wasted through feces. Meanwhile, analysis of variance showed that the NDF fibre uptake was not significantly different between treatments.

\section{CONCLUSION}

FCPH protein content is higher than $\mathrm{CPH}$ Fermentation increases the digestibility of protein and fibre. The product of $\mathrm{CPH}$ fermented using Aspergillus oryzae can replace commercial concentrates as much as 20 and $40 \%$ without causing negative effects for sheep.

\section{ACKNOWLEDGMENTS}

Thanks to Ms. Emma Ludia for helping with the enzyme assay.

\section{REFERENCES}

[1] J. Shvili. 2020. The Top Cocoa-Producing Countries. https://www.worldatlas.com/articles/top-10-cocoaproducing-countries.html. Accessed 27/9/2021 (Jason Shvili September 242020 in Economics)

[2] https://www.rikolto.org/en/project/cocoa-sulawesiindonesia . Accessed 27/9/2021

[3] T. Haryati dan I. Sutikno. 1994. Peningkatan nilai nutrisi kulit biji coklat melalui bioproses menggunakan beberapa jenis kapang. Ilmu dan Peternakan. 8.: 34-37

[4] M.D Toha.. Darlis dan A. Latief. 1998. Konversi pod coklat oleh kapang Aspergillus niger untuk produksi pakan ternak. J. Ilmu-ilmu Peternakan I (2): 1-5.

[5] I.N Purnama. 2004. Kajian potensi isolat kapang pemecah ikatan tanin pada kulit buah kakao (Theobroma cacao L.). Skripsi. Prodi Nutrisi dan 
Makanan Ternak. Fakultas Peternakan. Institut Pertanian Bogor. Bogor

[6] K.G Suparjo. I.K.D Wiryawan. E.B. Laconi dan D. Mangunwidjaja. 2009. Perubahan komposisi kimia kulit buah kakao akibat penambahan mangan dan kalsium dalam biokonversi dengan kapang Phanerochaete chrysosporium. Media Peternakan. 32 (3): 203-210.

[7] F. Alemawor. V.P. Dzogbefia. Emmanuel O.K. Oddoye and J .H. Oldham 2009. Enzyme cocktail for enhancing poultry utilisation of cocoa pod husk Francis Scientific Research and Essay. 4 : 555-559

[8] S.I.W Rakhmani. T. Purwadaria . 2017. Improvement of nutritional value of cocoa pod husk fermented with Aspergillus Spp. and two levels of urea and ammonium sulphate. JITV 22(3): 101-113. DOI: http://dx.doi.org/10.14334/jitv.v22i3.1670

[9] T. Purwadaria, T. Haryati, J. Darma, S. Kompiang, P. Kompiang and A.P. Sinurat. 1994. Pengembangan pembuatan inokulum Aspergillus niger untuk fermentasi cassapro. Proc. Nat. Symp. Science and Technology for Animal Husbandry, Bogor, Indonesia, pp. 727

[10] S. Calsamiglia.S and M.D. Stern. M.D 1995. A three-step in vitro procedure for estimating intestinal digestibility of protein in ruminants $\mathbf{J}$. Anim. Sci.. 73 (1995). pp. 1459-1465

[11] W. Puatuti. D. Yulistiani. I-W. Matghius. F. Giyai and E. Dihansih. 2010. Cacao pod based ration supplemented with organic $\mathrm{Zn}$ : Growth responce of sheep. JITV 15(4): 269-277.

[12] Nguyen Van Lai and Nguyen Thi Thu Huong. 1999. Comparison of the in sacco rumen and washing loss methods to estimate the potential energetic value for livestock of leaves from tropical trees, shrubs and crop residues. Livestock Research for Rural Development $11 \quad$ (1) http://www.lrrd.org/lrrd11/1/lai111.htm

[13] A. Melesse, F. Nigatu, A. Nurfeta. 2017. Effect of Replacing Wheat Bran with Air Dried Moringa stenopetala Pod on Nutrient Intake, Digestibility and Growth Performances of Yearling Sheep. Eth. J. Anim. Prod. 17(1) : 54-70. 